\title{
Sustainability of the Dairy Industry: Emissions and Mitigation Opportunities
}

\author{
Carlyn B. Peterson and Frank M. Mitloehner* \\ Department of Animal Science, University of California, Davis, Davis, CA, United States
}

Dairy cattle provide a major benefit to the world through upcycling human inedible feedstuffs into milk and associated dairy products. However, as beneficial as this process has become, it is not without potential negatives. Dairy cattle are a source of greenhouse gases through enteric and waste fermentation as well as excreting nitrogen emissions through their feces and urine. However, these negative impacts vary widely due to how and what these animals are fed. In addition, there are many promising opportunities for further reducing emissions through feed and waste additives. The present review aims to further expand on where the industry is today and the potential avenues for improvement. This area of research is still not complete and additional information is required to further improve our dairy systems impact on sustainable animal products.

OPEN ACCESS

Edited by:

Pasquale De Palo,

University of Bari Aldo Moro, Italy

Reviewed by:

Andrea Bragaglio,

University of Bari Aldo Moro, Italy

Andrea Vitali,

University of Tuscia, Italy

*Correspondence:

Frank M. Mitloehner

fmmitloehner@ucdavis.edu

Specialty section:

This article was submitted to Animal Physiology and Management,

a section of the journal

Frontiers in Animal Science

Received: 18 August 2021 Accepted: 17 September 2021

Published: 18 October 2021

Citation:

Peterson CB and Mitloehner FM (2021) Sustainability of the Dairy Industry: Emissions and Mitigation

Opportunities.

Front. Anim. Sci. 2:760310. doi: 10.3389/fanim.2021.760310
Keywords: cows, sustainability, greenhouse gases, methane, ammonia, enteric emissions, waste emissions

\section{INTRODUCTION}

Dairy production is considered a major societal asset globally due to its economic and nutritional benefits. In 2019 alone global milk production totaled 851.8 million tons in milk equivalents (Outlook, 2020). This contributes to substantial trade impacts, totaling about 76.7 million tons in 2019, as well as major per capita consumption at about $111.4 \mathrm{~kg} / \mathrm{year}$ globally (Outlook, 2020). There are over 245 million dairy cows worldwide that on average produce $2,300 \mathrm{~kg}$ per year; although average production is less informative as there is such a major disparity between production in different countries (FAO, 2009). This vast amount of milk production has a major global benefit-for human health, society, and the economy. In countries with developing economies livestock serve many purposes including: a source of household income, a financial asset for women, a source of food security, risk management, and a direct link to human health (Herrero et al., 2013). These benefits increase substantially when viewed from a macro lens. Global dairy imports totaled over $\$ 42.2$ billion in 2014 and global dairy exports expanded 175\% from 2005 to 2014 (Davis and Hahn, 2016). There are many dairy commodities being produced and traded as part of these exports with whole milk powder being the highest, followed by skim milk powder, butter, and cheese (Outlook, 2020). India is the largest dairy producer globally, with $22 \%$ of global production and $52,841,810$ total dairy cattle, the US is second in production, followed by China, Pakistan, and Brazil (FAO, 1997; Knips, 2005). While the US may not be the largest global milk producer, the total economic benefit of the dairy industry is substantial, totaling $\$ 628.27$ billion dollars in 2018 (O'Keefe, 2018). There are currently $9,336,000$ dairy cows in the U.S. that on average produce $10,610 \mathrm{~kg}$ of milk each year, which amassed to over $99,056,409 \mathrm{~kg}$ of milk in 2019 (USDA, 2020). The US dairy sector also generates over 2.9 million jobs either through direct or indirect support (O'Keefe, 2018). The 
top five milk producing states in the US are California, Wisconsin, Idaho, New York, and Texas, with California accounting for nearly $20 \%$ of national production (Sumner and Matthews, 2019; USDA, 2020). The dairy industry is such a major part of California's economy that in 2019 the associated impact from milk production and processing was about $\$ 57.7$ billion dollars, providing over 179,900 jobs (Sumner and Matthews, 2019). Dairy is the leading agricultural commodity produced in California, accounting for nearly $13 \%$ of the $\$ 49.9$ billion dollars in cash receipts generated for the top ranked agriculture producing state (CDFA, 2019). Not only is the dairy industry a major driver of the economy but its products serve a substantial nutritional benefit to the growing human population.

Milk and dairy products are a well-known source of calcium, vitamins, and other selected minerals as well as being a complete high-quality protein. One of the most well-documented nutritional benefits of dairy products is for bone healthparticularly for its ability to prevent osteoporosis and other bone diseases. In particular the calcium in milk positively affects bone mass in children and when coupled with vitamin $\mathrm{D}$, as seen in fortified milk products, will prevent bone loss and osteoporotic fractures in aging populations (Caroli et al., 2011). For low-income countries struggling with nutritional deficiencies in children, studies have shown that supplementation with dairy products causes a significant increase in vitamin B-12 plasma concentrations, improves cognition, growth and activity (Allen, 2003; Siekmann et al., 2003). In addition, maternal milk intake during pregnancy is positively associated with infant birth weight, and subsequent bone mineral content during childhood (Gil and Ortega, 2019). Other milk components, including bioactive peptides present in the whey components of milk were shown to benefit the immune system due to their antimicrobial and immunomodulatory properties (Madureira et al., 2010). Consumption of dairy products has shown an inverse relationship with cardiovascular disease in that consumption of milk and dairy is associated with a lower incidence of type-2 diabetes and improvements in glucose homeostasis (Hirahatake et al., 2014). While milk is relatively high in saturated fat it has been shown that milk intake did not increase cardiovascular risk (Visioli and Strata, 2014). Furthermore, milk intake was associated with reduced risk of childhood obesity as well as improved body composition and weight loss in adults (Thorning et al., 2016). Dairy intake was also shown to be inversely associated with incidence of cancer including colorectal, bladder, gastric, and breast cancer and was not shown to be associated with any other additional forms of cancer (Thorning et al., 2016). Although dairy production serves many benefits to overall nutrition, human health, and the economy, there has been increasing concern about the impact of dairy on the environment.

\section{Impact of Dairies on Climate Change and Air Quality}

The earth's surface has undergone massive increases in temperature, primarily in the last three decades, and the last 30 years we have seen the warmest period ever recorded (IPCC,
2014). In addition to this temperature increase, there have been other major changes to the climate including trends of increasing ocean temperature, rising sea level, as well as a major increase in greenhouse gas emissions (IPCC, 2014). Another phenomenon that has occurred over the last few centuries is an increase in ocean uptake of $\mathrm{CO}_{2}$, causing ocean acidification and a decrease in surface water $\mathrm{pH}$, as well as a rapid decrease in glaciers and ice sheets around the globe. These major changes in the climate are primarily due to anthropogenic (human caused) emissions of GHGs that have steadily increased since the beginning of the industrial revolution in the 1750s (Place and Mitloehner, 2010). Atmospheric concentrations of $\mathrm{CO}_{2}, \mathrm{CH}_{4}$, and $\mathrm{N}_{2} \mathrm{O}$ are also the highest they have been in at least the last 800,000 years, with about $78 \%$ of these $\mathrm{CO}_{2}$ emissions resulting from industrial processes and the combustion of fossil fuels (IPCC, 2014). Several studies have indicated that the production of livestock, including the stages of growing, transport, processing, and consumption have a relatively large impact on climate change (de Vries and de Boer, 2010; Milani et al., 2011). Dairy cattle in particular were shown to impact the environment through their potential negative contributions to air, water, and land (Naranjo et al., 2020).

In regards to the environment, the US Dairy industry has seen substantial improvements over the years. In particular it has seen a great increase in milk production primarily due to dramatic increases in milk production per cow, increase in average cow numbers per farm, as well as an overall decrease in total animal numbers (Wolf, 2003; Barkema et al., 2015). Some other major changes over the last 50 years include a shift to a primarily Holstein dairy herd (90\%), an increased heifer growth rate, decreased age at first calving, and an increase in the use of artificial insemination (Capper et al., 2009). Nutrition of dairy animals has also allowed for a substantial improvement in production via use of total mixed-rations balanced for nutrient and energy requirements accounting for each animals age and stage of lactation (National Research Council, 2001). Genetic selection has also been a major driver in increased productivity, longevity, and efficiency of dairy cows, further reducing the environmental impact per unit of milk production (Pryce and Haile-Mariam, 2020). These improvements in nutrition and genetics, in conjunction with improvements to herd management, accomplished primarily through increasing density on dairy farms, have resulted in a fourfold increase in milk yield from the mid-1940s until 2007 (Von Keyserlingk et al., 2013). This efficiency of milk production has continued to improve to 2014 where $1 \mathrm{~kg}$ of energy and protein corrected milk (ECM) for California emitted between 1.12 and $1.16 \mathrm{~kg}$ of $\mathrm{CO}_{2}$ equivalents $\left(\mathrm{CO}_{2} \mathrm{e}\right)$ in 2014 compared with $2.11 \mathrm{~kg}$ of $\mathrm{CO}_{2} \mathrm{e}$ in 1964 , resulting in a $45 \%$ reduction in $\mathrm{CO}_{2} \mathrm{e}$ (Naranjo et al., 2020). The dairy industry has continued to still further these improvements. Dairy production systems in 2017 compared with 2007 have reduced their inputs by $25.2 \%$ for animal numbers, $17.3 \%$ for total feed, $20.8 \%$ for land, and $30.5 \%$ for water of one million metric ton of energy-corrected milk, furthering the exceptional productivity gains and environmental progress of the industry (Capper and Cady, 2020). Even with these major advancements made over the last century, dairy systems still impact the environment 
through: GHG emissions from enteric fermentation, manure management, and feed production, water use for feed production and milk processing, water quality with contaminants including nitrogen $(\mathrm{N})$ and phosphorous $(\mathrm{P})$ from manure, as well as the requirement for land used in feed production (Naranjo et al., 2020). In addition to the direct impacts of cattle, such as $\mathrm{N}$ and $\mathrm{P}$ as a result of dairy production systems, there are also environmental impacts associated with dairy processing and subsequent production (Milani et al., 2011).

\section{Manure Emissions From Dairy Cattle}

Dairy manure has the potential to negatively impact the environment. Nitrogen not retained by the animal or secreted in milk will be excreted in the urine and feces of the animal (Hristov et al., 2019). Urine is more susceptible to losses of $\mathrm{N}$ to the environment from the animal waste as compared with fecal $\mathrm{N}$ (Dijkstra et al., 2013, 2018a). Dairy waste is a significant source of $\mathrm{N}$ and $\mathrm{P}$ that when land applied in excess of crop requirements can cause contamination of surface water (Knowlton and Cobb, 2006). This excess $N$ and $P$ in water causes a rapid bloom in the growth of algal populations that consume dissolved oxygen in water, termed eutrophication, which reduces the available dissolved oxygen required for growth of aquatic animal life (Knowlton and Cobb, 2006). Excess N can also contaminate ground water through leaching. This poses a problem for human and animal health as consumed nitrate from drinking water is converted to nitrite in the digestive tract, which replaces oxygen in hemoglobin and leads to cyanosis (oxygen starvation) (Knowlton and Cobb, 2006).

Air quality also affects human and animal health as well as the environment, and dairy cattle have been known to contribute to poor air quality. One such compound that affects air quality produced by dairy cattle is $\mathrm{NH}_{3}$. Ammonia is produced when $\mathrm{N}$ in urea from the animal's urine reacts with urease present in feces (Place and Mitloehner, 2010). Ammonia production from dairy waste is dependent on a variety of factors including: urea content in urine, $\mathrm{pH}$, and temperature, as well as the enzymatic activity of urease (Muck, 1982; Sun et al., 2008). In addition to $\mathrm{NH}_{3}$ losses from fresh waste, volatilization can occur during waste application to soil as a fertilizer, as well as during the long term housing and storage of manure (Bussink and Oenema, 1998). Total losses of $\mathrm{NH}_{3}$ can be between 0.82 and $250 \mathrm{~g}$ $\mathrm{NH}_{3} /$ cow/day, with the total loss dependent on the amount and composition of animal waste as well as the environment and management conditions of the manure storage (Bussink and Oenema, 1998; Hristov et al., 2011). Dairy waste management strategies greatly influence air emissions of $\mathrm{NH}_{3}$. The greatest $\mathrm{NH}_{3}$ emissions occur after field application, followed by the manure management strategies, for example, separated liquid and solids, aerated, straw covered, untreated, then anaerobic digested (Amon et al., 2006).

Nitrogen in waste can also contribute to GHG production through the formation and volatilization of nitrous oxide $\left(\mathrm{N}_{2} \mathrm{O}\right)$. Nitrous oxide is created during incomplete microbial denitrification process where nitrate is converted to $\mathrm{N}$ gas with the potential to create $\mathrm{N}_{2} \mathrm{O}$, an extremely volatile byproduct (Place and Mitloehner, 2010). Land applied dairy manure on cropland as well as the long term storage of manure in lagoons can contribute to emissions of $\mathrm{N}_{2} \mathrm{O}$ (Velthof et al., 1998; Place and Mitloehner, 2010). The $\mathrm{N}_{2} \mathrm{O}$ emissions during storage depend on the $\mathrm{N}$ and carbon content of the manure (Amon et al., 2006). Nitrous oxide production and subsequent volatilization is also dependent on environment and management. Higher temperatures as well as surface coverings contribute to increasing emissions, whereas anaerobic conditions, such as those found in lagoon systems, have lower $\mathrm{N}_{2} \mathrm{O}$ emissions (Dustan, 2002). The process of long term storage of manure seems to also contribute a larger proportion of $\mathrm{N}_{2} \mathrm{O}$ emissions compared with land application with aerated, straw covered, digested, separated, and untreated manure contributing decreasing amounts of $\mathrm{N}_{2} \mathrm{O}$ emissions (Amon et al., 2006).

Another substantial GHG produced by dairy cattle waste is methane $\left(\mathrm{CH}_{4}\right)$. The amount of $\mathrm{CH}_{4}$ emitted by dairy waste is dependent on the amount of carbon, hydrogen, and oxygen present in the waste, making manure storage, diet, and bedding major contributors to total $\mathrm{CH}_{4}$ production (Place and Mitloehner, 2010). A smaller proportion of $\mathrm{CH}_{4}$ is also produced in the hindgut of the animal via post ruminal digestion and fermentation (Ellis et al., 2008). This $\mathrm{CH}_{4}$ is mostly absorbed from the hindgut (89\%) and eventually eructated by the animal or excreted with the manure (11\%) (Murray et al., 1976; Immig, 1996; de la Fuente et al., 2019). Manure $\mathrm{CH}_{4}$ emissions are substantially higher from long term storage compared with field application (Amon et al., 2006). These emissions are highest from straw covered manure and emissions decrease with untreated manure, followed by separation, aeration, and digested manure management methods (Amon et al., 2006).

Dairy waste can also produce volatile organic compounds (VOC). Volatile organic compounds are a class of chemicals that when reacted with oxides of $\mathrm{N}$ and sunlight contribute to ozone formation (Place and Mitloehner, 2010). There were 73 detectable VOCs from slurry wastewater lagoons with the most common VOCs being methanol, acetone, propanal, and dimethylsulfide (Filipy et al., 2006; Shaw et al., 2007). As with other waste emissions, VOCs from dairy waste increase with ambient air temperature with summer months having the highest rates of VOC emissions (Filipy et al., 2006). The largest contribution of VOCs on dairy systems come from fermented feedstuffs (i.e., silage) (Place and Mitloehner, 2010).

\section{Effect of Nutrition on Emissions From Dairy Cattle}

Dairy cattle enteric emissions have been shown to contain a variety of gases. For example dairy cattle emit $\mathrm{CO}_{2}$ as a byproduct of aerobic cellular respiration, which is the GHG with the greatest contribution to climate change (Place and Mitloehner, 2010). However, this gas is not considered a net contributor to the rise in GHGs due to the $\mathrm{CO}_{2}$ having been previously recycled from the atmosphere by fixation during photosynthesis in plants, which are then consumed by the cattle (Steinfeld et al., 2006). Dairy cattle can also produce $\mathrm{N}_{2} \mathrm{O}$ from enteric emissions as a result of the $\mathrm{NO}_{3}$ reduction process that takes place by the microbes in the rumen (Kaspar and Tiedje, 1981). Due to the small production of 
enteric $\mathrm{N}_{2} \mathrm{O}$, these emissions are not always considered in dairy emission analyses (Casey and Holden, 2005).

The most significant enteric emission compound from dairy cattle is $\mathrm{CH}_{4}$. Methane acts as a hydrogen sink in the rumen and is an end product of $\mathrm{CO}_{2}$ reduction by methanogenic archaea (Janssen and Kirs, 2008). Methanogens serve an important role in rumen health by removing this hydrogen that can be toxic to some bacterial communities and also causes the disease state rumen acidosis (Beauchemin et al., 2009). In addition to being a potent GHG, $\mathrm{CH}_{4}$ also accounts for a $2-12 \%$ loss of potential energy available to the animal that could otherwise be used for maintenance and productive purposes as growth gestation, or lactation (Moe and Tyrrell, 1979).

Dairy cattle diets have a significant impact on enteric emissions, mostly $\mathrm{CH}_{4}$. As there is large variability in the ingredient and chemical composition of diets fed to dairy cattle, nutrition and feeding strategies have the greatest potential for reducing $\mathrm{CH}_{4}$ emissions, with potential reported reductions between 2.5 and 15\% (Knapp et al., 2014). The amount of $\mathrm{CH}_{4}$ produced is dependent on many factors including intake and chemical composition of the carbohydrate, retention time of feed in the rumen, rate of fermentation of different feedstuffs, as well as the rate of methanogenesis (Beauchemin et al., 2009). Altering feed digestibility and chemical composition cause a shift in the proportions of volatile fatty acids (VFA) with the predominant VFAs being propionate, butyrate, and acetate (Knapp et al., 2014). This shift in VFA proportion is important because propionate also acts as a hydrogen sink so shifting from acetate and butyrate formation to propionate will consume reducing equivalents and help preserve the $\mathrm{pH}$ balance in the rumen (Hungate, 2013). An overall reduction in $\mathrm{CH}_{4}$ emissions or a shift in VFAs can be accomplished through a variety of altered feeding strategies. More energy dense or more digestible feedstuffs result in additional energy available to the animal and generate less $\mathrm{CH}_{4}$ from fermentation (Knapp et al., 2014). An increase in starch proportion of the diet, such as through an increase in concentrate levels, also results in a more rapid fermentation of these feedstuffs and therefore decreased $\mathrm{CH}_{4}$ production (Moe and Tyrrell, 1979; Johnson and Johnson, 1995). Feeding higher starch diets requires increased grain production, which can cause additional consumption of fossil fuel and fertilizers that results in an increase in $\mathrm{N}_{2} \mathrm{O}$ and $\mathrm{CO}_{2}$; however, this system is usually offset by the substantial decrease in overall in $\mathrm{CH}_{4}$ emissions (Johnson et al., 2002; Lovett et al., 2006). Feeding of cereal forages can also favor propionate production and reduce $\mathrm{CH}_{4}$ emissions due to the higher starch concentration (Beauchemin et al., 2009). Higher concentrations of legumes, such as alfalfa, when compared with grass forage based diets can also lead to an overall decrease in $\mathrm{CH}_{4}$ emissions (McCaughey et al., 1999). Age of harvest of forage also has a significant impact on emissions, with advancing maturity resulting in more lignified and less fermentable substrate contributing to increasing emissions associated with higher ruminal acetate (Pinares-Patiño et al., 2003). In addition to alterations in forage or concentrate composition and ratio, supplementation of lipids to dairy cattle diets can also mitigate enteric emissions (Hristov et al., 2013b). Replacing concentrates with lipids results in a decrease in fermentable substrate by the microbes in the rumen and can also decrease total protozoa and methanogen populations (Ivan et al., 2004). An inclusion of high-oil by-products, such as distillers grains or oilseed meals, can result in decreased $\mathrm{CH}_{4}$ emissions (Hristov et al., 2013b). Research on ensiled feeds in relation to enteric emissions is generally lacking, although it is anticipated that corn silage will mitigate emissions due to its higher starch content (Gerber et al., 2013). Furthermore, when directly comparing grass-versus corn silage, a higher inclusion of corn silage seems to mitigate enteric $\mathrm{CH}_{4}$ emissions (Mills et al., 2008; Doreau et al., 2012). There are many potential methods to mitigate enteric emissions through alterations to nutrition strategy and composition.

Manure emissions are also significantly impacted by various dairy cattle feeding strategies. One of the main issues with altering feeding strategies to reduce enteric emissions is that fermentable substrate in the manure can increase, as has been seen with increasing the concentrate to forage ratio in the diet (Hindrichsen et al., 2006; Beauchemin et al., 2009). This response has also been seen with the supplementation of certain fatty acids (Kreuzer and Hindrichsen, 2006). To alleviate this issue, feeding concentrate with higher lignified fiber has been shown to mitigate both enteric and manure-derived emissions (Kreuzer and Hindrichsen, 2006; Aguerre et al., 2012). These changes to concentrate ratio do not have an impact on $\mathrm{N}$ containing manure emissions, as would be expected (Hindrichsen et al., 2006; Aguerre et al., 2012). The greatest impact of diet on waste emissions can be seen when feeding low crude protein (CP) diets to dairy animals, which results in decreased excreted $\mathrm{N}$ and subsequent $\mathrm{NH}_{3}$ volatilization (Cardenas et al., 2007; Lee et al., 2012; Edouard et al., 2019). Comparing fresh grass with prepared hay at the same $\mathrm{CP}$ content, feeding hay causes a higher overall $\mathrm{N}$ and $\mathrm{C} / \mathrm{N}$ ratio excreted but waste from grass fed animals tends to volatilize more $\mathrm{NH}_{3}$ emissions (Külling et al., 2003). Corn silage inclusion in diets has also caused changes to manure emission profiles. For example when comparing corn silage versus grass silage, corn silage tended to reduce urinary $\mathrm{N}$ excretion (Mills et al., 2008). When adding corn silage to alfalfa silage based diets there is also an improvement in $\mathrm{N}$ efficiency leading to a decrease in $\mathrm{N}$ losses in urine and subsequent decreases in available $\mathrm{NH}_{3}$ and $\mathrm{N}_{2} \mathrm{O}$ volatilization (Gerber et al., 2013). Higher sugar forages also reduce $\mathrm{N}$ excretions, which also have the potential to limit the $\mathrm{N}$ available to be volatilized as gaseous emissions (Miller et al., 2001; Parsons et al., 2012; Gerber et al., 2013). Overall a variety of feeding strategies can be employed to help mitigate emissions from enteric and waste sources of dairy animals.

\section{Mitigation Strategies for Dairy Cow Enteric Gas Emissions}

In addition to changes to the diet ingredient composition, there are also additives to diets that may mitigate enteric emissions. While there are various types of strategies to alter enteric sourced emissions this section will focus primarily on methods to alter $\mathrm{CH}_{4}$. One promising strategies for $\mathrm{CH}_{4}$ reduction is via feed supplementation of the methanogenic inhibitor, 3Nitrooxypropanol (3-NOP). 3-Nitrooxypropanol is a structural 
analog to methyl-coenzyme $\mathrm{M}$, which acts on methyl-coenzyme $M$ reductase (MCR), a nickel enzyme involved in the final reduction stages of methanogenesis (Duin et al., 2016). In the rumen system 3-NOP was shown to mimic methyl-coenzyme M and target the active site of MCR, thus inhibiting the enzymes activity and subsequently causing a decrease in $\mathrm{CH}_{4}$ production (Duin et al., 2016). Research demonstrated that feeding 3-NOP to cattle decreased enteric $\mathrm{CH}_{4}$ emissions up to $95 \%$ in vitro (Martínez-Fernández et al., 2014) and $84 \%$ in vivo (Vyas et al., 2016). 3-NOP was tested in vivo in multiple ruminant models including sheep (Martínez-Fernández et al., 2014), beef cattle (Romero-Perez et al., 2015; Vyas et al., 2016), as well as Holstein dairy cattle (Reynolds et al., 2014; Hristov et al., 2015; Lopes et al., 2016; Haisan et al., 2017). Reynolds et al. (2014) fed 3NOP at a rate of either 500 or $2,500 \mathrm{mg} / \mathrm{d}$ via rumen fistula before each feeding and using respiration calorimetry found a reduction of 6.6 and $9.8 \%$ in $\mathrm{CH}_{4}$ emissions, respectively. They also found a decrease in dry matter intake (DMI) and an increase in milk protein at the higher dose, without other changes in production parameters. Haisan et al. (2017) also fed 2,500 mg/d and using the SF6 systems measured a reduction in emissions from 17.8 to $7.18 \mathrm{~g} / \mathrm{kg}$ of DMI without adverse effects to milk or DMI. Hristov et al., 2015 fed 3-NOP at a rate of 40, 60, or 80 $\mathrm{mg} / \mathrm{kg}$ of DMI and measured reductions via a GreenFeed system of 25,31 , and $32 \%$, respectively. They also found no changes to DMI or milk production with an increase in protein yield following supplementation. Similarly, Lopes et al. (2016) also fed $60 \mathrm{mg} / \mathrm{kg}$ of DMI and found a 31\% decrease in emissions with an increase in milk fat concentration. Dijkstra et al. (2018b) evaluated the overall efficacy of 3-NOP in research trials and determined that greater $3-\mathrm{NOP}$ dose results in a greater reduction of $\mathrm{CH}_{4}$ emissions. These trials also used different diets, which did not seem to effect the impact of 3-NOP on emissions. However, this molecule has yet to be evaluated for its efficacy among different dairy breeds and the potential side effects of its use have not fully elucidated. Additionally, it has yet to be determined whether 3-NOP has any unintended consequences of carryover to the excreta of supplemented animals.

Nitrates offer great promise for their potential to mitigate $\mathrm{CH}_{4}$ and have been well studied for their use in beef cattle diets with more recent literature focusing on the potential for use in dairy cattle. Nitrate in the diet serves as a non-protein $\mathrm{N}$ source that acts as an electron receptor resulting in effective and consistent reduction of enteric emissions. However, nitrate has the potential to induce methemoglobinaemia and is a known carcinogen (Lee and Beauchemin, 2014). Nitrate toxicity can generally be avoided when the rumen ecosystem is allowed time to adapt (Hristov et al., 2013b). Even with the potential for toxicity, the benefits of $16-50 \%$ reduction in $\mathrm{CH}_{4}$ emissions continue to drive research feeding nitrates (Leng and Preston, 2010). Van Zijderveld et al. fed nitrate at a rate of $21 \mathrm{~g} / \mathrm{kg}$ DMI and measured a persistent reduction in $\mathrm{CH}_{4}$ of $16 \%$ via use of open-circuit indirect calorimetry chambers (Van Zijderveld et al., 2011). They did not measure changes in milk yield or DMI for the supplemented animals. Similar research conducted by other authors found a reduction in emissions of $\mathrm{CH}_{4} / \mathrm{d}$ from $363 \mathrm{~g}$ for control animals to $263 \mathrm{~g}$ for nitrate supplemented animals also at $21 \mathrm{~g} / \mathrm{kg}$ DMI (Klop et al., 2016). They also measured a reduction in milk protein concentration as well as DMI for nitrate-supplemented cows. When high levels of nitrate (20 g/ $\mathrm{kg}$ DMI) were supplemented in a similar study design they found a $31 \%$ reduction in $\mathrm{CH}_{4}$ along with a decrease in DMI during nitrate feeding (Lund et al., 2014). Another study found a $28 \%$ decrease in methanogenesis after feeding nitrate at $2.3 \%$ of DM to nonlactating cows, however they also found a significant decrease in feed intake from the supplemented animals (Guyader et al., 2015). Another trial reported a $10 \%$ decrease in DMI, coupled with a $17 \%$ decrease in $\mathrm{CH}_{4}$ where dairy cattle diets were supplemented with nitrate at 1.5\% of DMI (Meller et al., 2019). A meta-analysis found a persistent reduction in $\mathrm{CH}_{4}$ emissions in both in vitro and in vivo studies (Lee and Beauchemin, 2014). Similar to 3-NOP, TMR composition did not seem to have a major effect on nitrate supplementation as these studies all saw a significant decrease in emissions with vastly different diets.

Plant biological compounds have also been explored for their potential to reduce emissions. Condensed tannins are secondary phenolic compounds that generally discourage consumption by herbivories and also concentrate $\mathrm{N}$ in the plant (Waghorn, 2008). When consumed by dairy cattle these tannins bind protein in the rumen, which reduces the degradation of protein and enhances protein flow to the intestines (Beauchemin et al., 2009). Tannin source appeared to make a major difference in subsequent mitigation of $\mathrm{CH}_{4}$ emissions from dairy cattle. For example, the Hedysarum coronarium species supplemented at $27 \mathrm{~g} / \mathrm{kg}$ DMI resulted in lower $\mathrm{CH}_{4}$ emissions by dairy cattle (Woodward et al., 2002). Whereas, Schinopsis quebracho-colorado supplemented at 0,1 , or $2 \%$ of dietary DM did not have any effect on enteric emissions or dry matter intake of beef cattle (Beauchemin et al., 2007). Additional studies looking at Lotus pedunculatus (fed at $10 \%$ of dry matter) and Medicago sativa (fed at $0.1 \%$ of dry matter) tannin supplementation found decreased $\mathrm{CH}_{4}$ emissions from both strains of condensed tannins, although DMI was not measured, which were attributed to reducing hydrogen production and direct inhibition on methanogenic archaea (Tavendale et al., 2005). A meta-analysis identified a general anti-methanogenic effect of tannins across different sources and that the variation in methane reduction seen in previous studies may have been due to the low tannin levels used in those trials (Jayanegara et al., 2012). They also found that dietary tannins tended to increase DMI but decrease total tract digestibility, apparent CP digestibility, and neutral detergent fiber digestibility. As with previous feed supplementation, these trials did not quantify emission changes to waste sources. Additional research into tannins in various diets as well as its effect on milk production and manure $\mathrm{CH}_{4}$ emissions needs to be explored.

In addition to tannins, secondary plant compounds called essential oils have been explored for their antimicrobial properties. Essential oils are naturally occurring volatile components in plants that provide the plant specific color and flavor characteristics (Benchaar et al., 2008). Essential oils reduced $\mathrm{CH}_{4}$ production through inhibiting growth and energy metabolism of selected bacteria and archaea including methanogens (Benchaar et al., 2008). Over 250 essential oils have been identified and contain mixtures of terpenoids, a variety of 
low molecular weight aliphatic hydrocarbons, alcohols, acids, aldehydes, acrylic esters, $\mathrm{N}$, sulfur, coumarins, and homologs of phenylpropanoids (Beauchemin et al., 2009). These essential oils underwent in vitro screening for their potential to reduce rumen $\mathrm{CH}_{4}$ emissions and while 35 were found to be effective only six were found to have significant decreases in emissions without disrupting digestibility (Bodas et al., 2008). It is difficult to directly compare essential oils because of the number of different compounds as well as the difference in study design and species studied. In addition, few essential oils have been thoroughly evaluated in vivo. Benchaar and Greathead (2011) performed additional in vitro testing and found decreased $\mathrm{CH}_{4}$ production following supplementation with oregano, rhubarb, thyme, cinnamon, horse radish, frangula, and garlic. Tekippe et al. (2011) fed oregano leaf at a rate of $500 \mathrm{~g} / \mathrm{d}$ to lactating dairy cattle and measured rumen $\mathrm{CH}_{4}$ production $8 \mathrm{~h}$ after feeding. They found a decrease in total $\mathrm{CH}_{4}$ yield but did not see adverse effects on DMI or milk yield with the added benefit of increased milk fat content. In a follow up study by Hristov et al. (2013a) they fed lactating dairy cows 250,500 , and $750 \mathrm{~g}$ of oregano leaf per day and found a linear reduction in methane per unit of DMI coupled with a linear decrease in DMI but no differences in any milk production parameters. In addition to particular isolates of essential oils, there are also commercial essential oil blends being marketed for their potential to reduce enteric $\mathrm{CH}_{4}$. One essential oil blend is Agolin SA created in Bière, Switzerland that is comprised of coriander oil, geranyl acetate, and eugenol. Agolin was tested in vitro and found a significant initial decrease in rumen $\mathrm{CH}_{4}$, but the effect did not persist over time (Klop et al., 2017b). Another Agolin in vitro trial found similar results where there was an initial reduction in methane, but the effect was not constant over the total $72 \mathrm{~h}$ incubation period (Castro-Montoya et al., 2015). These authors also conducted feeding trials with the Agolin essential oil product. Castro-Montoya et al. (2015) found a trend in reduction of daily emissions relative to intake and (Klop et al., 2017a) found initial decrease in $\mathrm{CH}_{4} / \mathrm{DMI}$ only for the first 2 weeks of feeding Agolin, after which Agolin did not impact $\mathrm{CH}_{4}$. In addition, Klop et al. (2017a) reported a decrease in DMI over the second half of the supplementation period. Hart et al. (2019) also supplemented lactating dairy cattle with Agolin essential oils and measured a reduction in $\mathrm{CH}_{4}$ emissions per pen. Changes to DMI, milk production, or fat composition after feeding of essential oils have also been reported following Agolin supplementation. For example, Santos et al., 2010 reported numerically lower DMI with an increase in milk fat production, a $0.03 \mathrm{~kg} /$ day increase in fat production, from Agolin supplemented cows, whereas Elcoso et al. (2019) saw an increase in ECM supplemented animals without differences in DMI. However, for Santos et al. (2010) the Agolin treatment was applied to the pen and not the individual animal. Elcoso et al. (2019) also estimated rumen $\mathrm{CH}_{4}$ production from fermented rumen fluid and found supplemented animals to be lower, but there was an interaction between the time and treatment. Hart et al. (2019) also found a greater milk yield and ECM for Agolin supplemented animals. Clearly the large discrepancy in responses across research studies for Agolin emphasizes the need for additional research to determine if the essential oil product has application at the farm level to reduce enteric $\mathrm{CH}_{4}$ emissions.

\section{Mitigation Strategies for Dairy Cow Manure Gas Emissions}

While there are many ways in which to alter manure emissions depending on the desired outcome this literature search will focus on methods to alter $\mathrm{CH}_{4}$ emissions specifically, of which there are quite a few promising strategies. One manure amendment strategy includes the use of biochar. Biochar is a general term applied to products produced by thermal decomposition from a variety of biomass substrates for agricultural applications including the added benefit of optimizing the process of composting (Godlewska et al., 2017). Biochar was shown to have a multitude of benefits including improving the overall process of composting, improving $\mathrm{N}$ conservation, facilitating nutrient transformation, and favoring oxygen supply (Vandecasteele et al., 2016; Chen et al., 2018; Mao et al., 2018). Other studies demonstrated that biochar improved soil physicochemical properties, benefited nutrient conservation as well as boosted crop production (Li et al., 2015; Mao et al., 2017; Wu et al., 2017). While the benefits of biochar as amendments to poultry and pig manure have been well-documented (Agyarko-Mintah et al., 2017; Chen et al., 2017; He et al., 2019), its use in dairy cattle manure management has been less thoroughly studied. Jindo et al. (2012) added biochar to cattle manure to measure microbial communities, causing a significant increase in the $\mathrm{C} / \mathrm{N}$ ratio from the additional of high carbon biochar materials, but they did not measure emissions from these systems. Duan et al. (2019) applied wood or wheat straw biochar with and without bacterial supplementation to cattle manure compost. While this study did not measure $\mathrm{CH}_{4}$ emissions specifically, they found that biochar in addition to bacterial amendments enhanced the compost overall and that Bacteroidales, Flavobacteriales, and Bacilli were the communities with the highest abundance in the samples. Awasthi et al. (2020) also tested biochar with and without a bacterial inoculum applied to fresh cattle manure in a reactor and found treatments with the inclusion of biochar produced substantially less $\mathrm{CH}_{4}$ as compared with the control. Overall, the impact and mechanism of action of biochar on $\mathrm{CH}_{4}$ emissions from dairy waste specifically deserves further study.

Bacterial inoculums, as well as the supplementation of bacterial produced enzymes, have been well-researched in the literature for their potential to alter $\mathrm{CH}_{4}$ emissions. Bacteria are involved in many of the breakdown processes that occur in manure management systems including reactions of hydrolysis, acidogenesis, acetogenesis, and methanogenesis, the latter of which has the potential to increase methane production (Juodeikiene et al., 2017). While increased $\mathrm{CH}_{4}$ may seem in conflict with the present literature review, this manure management strategy can be applied to systems where $\mathrm{CH}_{4}$ can be captured and transformed into biofuel or other renewable resources. One such example is through anaerobic digestion in which organic material is degraded by microbes in the absence of oxygen (Rodriguez Chiang, 2011). A variety of bacterial communities have been researched for their potential to change 
$\mathrm{CH}_{4}$ emissions from various substrates. Juodeikiene et al. studied Lactobacillus delbrüeckii, and found an increase in methane of $76 \%$ from dairy wastewater from milk processing, as compared with $38 \%$ without the addition of bacteria (Juodeikiene et al., 2017). Xu et al. pretreated corn straw with Bacillus subtilis, and increased $\mathrm{CH}_{4}$ production $17.35 \%$ above the untreated control (Xu et al., 2018). He et al. also supplemented microalgal biomass with Bacillus licheniformis, and bacterial supplementation increased $\mathrm{CH}_{4}$ production from 9.2 to $22.7 \%$ (He et al., 2016). Commercial products have also been marketed for their application in manure management systems, including BiOWiSH products. BiOWiSH products contain a proprietary mixture of Bacillus and Lactobacillus, including Bacillus subtilis, Bacillus amyloliquefaciens, Bacillus licheniformis, Bacillus pumilus, Pediococcus acidilactici, Pediococcus pentosaceus, Lactobacillus plantarum, Bacillus meagerium, Bacillus coagulans, and Paenibacillus polymyxia, a product covered by a patent outlined by Carpenter et al. (2014). The process to create BiOWiSH involves individually fermenting each organism, followed by harvesting and then drying of each organism. Finally, the dried organism ground to produce a powder with a final moisture content $<5 \%$ and a final bacterial concentration between $10^{5}$ and $10^{11}$ colony forming units (CFU) per gram of dried product. While these products have not been evaluated for their effect on $\mathrm{CH}_{4}$ specifically, these products claim to digest sludge, and reduce biological oxygen demand, total suspended solids, total Kjeldahl N, and odor from manure lagoons. The BiOWiSH product has been applied to dairy waste systems and showed promise for manure mitigation including: a reduction in total suspended solids and a degradation and removal of $N$ (Lee, 2012; Pal, 2012; Holland, 2017). However, BiOWiSH has not been studied with respect to its effects on $\mathrm{CH}_{4}$ emissions from dairy wastewater systems.

Gypsum based products have been applied to dairy waste systems for manure amendments. One of the more common forms of gypsum used for manure amendment is flue gas desulphurization gypsum that is a by-product of wet gas desulphurization from coal-fired power stations (Febrisiantosa et al., 2018). This gypsum has a low heavy metal content and contains high concentrations of $\mathrm{S}, \mathrm{Si}$, and $\mathrm{Ca}$ that are essential minerals nutrients required by plants (Guo et al., 2016). Gypsum has been fairly well-characterized for its effects on $\mathrm{N}$ containing compounds. Tubail et al. found gypsum supplemented dairy manure lost significantly less $\mathrm{N}$ as compared with the control dairy manure without supplementation (Tubail et al., 2008). Li et al. applied gypsum to pig manure compost and found significant reductions in $\mathrm{NH}_{3}$ and enhanced mineral and total $\mathrm{N}$ contents ( $\mathrm{Li}$ et al., 2018). Hao et al. applied gypsum to beef cattle manure and found a significant reduction in $\mathrm{CH}_{4}$ emissions from the medium and high doses of gypsum as compared with the control (Hao et al., 2005). Yang et al. studied kitchen waste compost and found the addition of gypsum to dramatically reduce $\mathrm{CH}_{4}$ emissions by $85.8 \%$ (Yang et al., 2015). While these study designs don't quite have the same application as is intended in this literature review, the potential for use of gypsum as a manure amendment is promising. There are also commercial additives being marketed for their potential to mitigate $\mathrm{CH}_{4}$ emissions, including SOP Srl, a company that makes the SOP Lagoon products. SOP Lagoon consists of calcium sulfate dihydrate (agricultural gypsum) that is processed with the company's proprietary technology. The product's claim is to improve liquid manure management through inhibiting the production and release of GHGs (e.g., $\mathrm{CH}_{4}$ and $\mathrm{N}_{2} \mathrm{O}$ ) and criteria pollutants (e.g., $\mathrm{NH}_{3}$ ) while also reducing the odor intensity from liquid manure. Borgonovo et al. first tested the gypsum-based commercial additive, "SOP LAGOON," on fresh dairy manure and found the additive to be effective in reducing direct $\mathrm{NH}_{3}$ and $\mathrm{GHG}$ emissions, including a significant mitigation of $\mathrm{CH}_{4}$ emissions (Borgonovo et al., 2019). Recent literature by Peterson et al. applied SOP Lagoon to liquid stored dairy cattle manure over a 2 week period and found similar results including significant reductions in $\mathrm{NH}_{3}$ emissions (22.7\% for the supplemented systems as compared with an unsupplemented control) (Peterson et al., 2020). With the strong literature documenting the potential for gypsum to decrease $\mathrm{CH}_{4}$ emissions, this seems like a viable manure amendment strategy.

In addition to the previously described additives, a variety of additional organic substrates have been applied as amendments in diverse applications. These additional amendments include lime and coal fly ash (Fang et al., 1999; Wong et al., 2009), zeolite (Awasthi et al., 2016; Chan et al., 2016), bentonite (Wang et al., 2016), clay (Chen et al., 2018), and medical stone (Awasthi et al., 2017; Wang et al., 2017), among others. These amendments require further research to evaluate their potential use in dairy manure specifically as well as the resulting $\mathrm{CH}_{4}$ emissions after their application.

\section{CONCLUSIONS}

There is an increasing amount of literature and research data concerning strategies to further reduce livestock's impact on the environment. However, there is no one method of environmental sustainability in these systems and even still there are many unanswered questions. Future research needs to better quantify full reduction potential and elucidate the mechanism of actions of these compounds including 3-NOP, tannins, essential oils, bacterial inoculums, and biochar, among others. Furthermore, slight alterations to dairy cattle diets can cause major changes in both enteric and waste emissions. Research on mitigating the environmental impact of dairy cattle will allow dairy producers to contribute to a more sustainable dairy production system.

\section{DATA AVAILABILITY STATEMENT}

The original contributions presented in the study are included in the article/Supplementary Material, further inquiries can be directed to the corresponding authors.

\section{AUTHOR CONTRIBUTIONS}

CP wrote the manuscript draft. All authors contributed to the article and approved the submitted version. 


\section{REFERENCES}

Aguerre, M., Wattiaux, M., and Powell, J. (2012). Emissions of ammonia, nitrous oxide, methane, and carbon dioxide during storage of dairy cow manure as affected by dietary forage-to-concentrate ratio and crust formation. J. Dairy Sci. 95, 7409-7416. doi: 10.3168/jds.2012-5340

Agyarko-Mintah, E., Cowie, A., Singh, B. P., Joseph, S., Van Zwieten, L., Cowie, A., et al. (2017). Biochar increases nitrogen retention and lowers greenhouse gas emissions when added to composting poultry litter. Waste Manage. 61, 138-149. doi: 10.1016/j.wasman.2016.11.027

Allen, L. H. (2003). Interventions for micronutrient deficiency control in developing countries: past, present and future. J. Nutrition 133, 3875S-3878S. doi: $10.1093 / \mathrm{jn} / 133.11 .3875 \mathrm{~S}$

Amon, B., Kryvoruchko, V., Amon, T., and Zechmeister-Boltenstern, S. (2006). Methane, nitrous oxide and ammonia emissions during storage and after application of dairy cattle slurry and influence of slurry treatment. Agric. Ecosyst. Environ. 112, 153-162. doi: 10.1016/j.agee.2005. 08.030

Awasthi, M. K., Duan, Y., Awasthi, S. K., Liu, T., and Zhang, Z. (2020). Effect of biochar and bacterial inoculum additions on cow dung composting. Bioresour. Technol. 297:122407. doi: 10.1016/j.biortech.2019.1 22407

Awasthi, M. K., Pandey, A. K., Bundela, P. S., Wong, J. W., Li, R., and Zhang, Z. (2016). Co-composting of gelatin industry sludge combined with organic fraction of municipal solid waste and poultry waste employing zeolite mixed with enriched nitrifying bacterial consortium. Bioresour. Technol. 213, 181-189. doi: 10.1016/j.biortech.2016.02.026

Awasthi, M. K., Wang, M., Chen, H., Wang, Q., Zhao, J., Ren, X., et al. (2017). Heterogeneity of biochar amendment to improve the carbon and nitrogen sequestration through reduce the greenhouse gases emissions during sewage sludge composting. Bioresour. Technol. 224, 428-438. doi: 10.1016/j.biortech.2016.11.014

Barkema, H. W., von Keyserlingk, M. A., Kastelic, J. P., Lam, T., Luby, C., Roy, J.-P., et al. (2015). Invited review: changes in the dairy industry affecting dairy cattle health and welfare. J. Dairy Sci. 98, 7426-7445. doi: 10.3168/jds.2015-9377

Beauchemin, K., McGinn, S., Martinez, T., and McAllister, T. (2007). Use of condensed tannin extract from quebracho trees to reduce methane emissions from cattle. J. Anim. Sci. 85, 1990-1996. doi: 10.2527/jas.2006-686

Beauchemin, K. A., McAllister, T. A., and McGinn, S. M. (2009). Dietary mitigation of enteric methane from cattle. CAB Rev. 4, 1-18. doi: 10.1079/PAVSNNR20094035

Benchaar, C., Calsamiglia, S., Chaves, A., Fraser, G., Colombatto, D., McAllister, T., et al. (2008). A review of plant-derived essential oils in ruminant nutrition and production. Anim. Feed Sci. Technol. 145, 209-228. doi: 10.1016/j.anifeedsci.2007.04.014

Benchaar, C., and Greathead, H. (2011). Essential oils and opportunities to mitigate enteric methane emissions from ruminants. Anim. Feed Sci. Technol. 166, 338-355. doi: 10.1016/j.anifeedsci.2011.04.024

Bodas, R., López, S., Fernandez, M., García-González, R., Rodríguez, A., Wallace, R., et al. (2008). In vitro screening of the potential of numerous plant species as antimethanogenic feed additives for ruminants. Anim. Feed Sci. Technol. 145, 245-258. doi: 10.1016/j.anifeedsci.2007.04.015

Borgonovo, F., Conti, C., Lovarelli, D., Ferrante, V., and Guarino, M. (2019). Improving the sustainability of dairy slurry by a commercial additive treatment. Sustainability 11:4998. doi: 10.3390/su11184998

Bussink, D., and Oenema O. (1998). Ammonia volatilization from dairy farming systems in temperate areas: a review. Nutr. Cycling Agroecosyst. 51, 19-33. doi: 10.1023/A:1009747109538

Capper, J. L., and Cady, R. A. (2020). The effects of improved performance in the US dairy cattle industry on environmental impacts between 2007 and 2017. J. Animal Sci. 98:skz291. doi: 10.1093/jas/skz291

Capper, J. L., Cady, R. A., and Bauman, D. E. (2009). The environmental impact of dairy production: 1944 compared with 2007. J. Anim. Sci. 87, 2160-2167. doi: $10.2527 /$ jas. $2009-1781$

Cardenas, L. M., Chadwick, D., Scholefield, D., Fychan, R., Marley, C. L., Jones, R., et al. (2007). The effect of diet manipulation on nitrous oxide and methane emissions from manure application to incubated grassland soils. Atmos. Environ. 41, 7096-7107. doi: 10.1016/j.atmosenv.2007.04.055
Caroli, A., Poli, A., Ricotta, D., Banfi, G., and Cocchi, D. (2011). Invited review: dairy intake and bone health: a viewpoint from the state of the art. J. Dairy Sci. 94, 5249-5262. doi: 10.3168/jds.2011-4578

Carpenter, R., Showell, M. S., Barnes, J., and Pal, N. (2014). Microbial-Based Waste Water Treatment Compositions and Methods of Use Thereof. Google Patents.

Casey, J., and Holden, N. (2005). Analysis of greenhouse gas emissions from the average Irish milk production system. Agric. Syst. 86, 97-114. doi: 10.1016/j.agsy.2004.09.006

Castro-Montoya, J., Peiren, N., Cone, J. W., Zweifel, B., V., Fievez, and De Campeneere S. (2015). In vivo and in vitro effects of a blend of essential oils on rumen methane mitigation. Livest. Sci. 180:134-142. doi: $10.1016 /$ j.livsci.2015.08.010

CDFA (2019). 2018-2019 California Agricultural Statistics Review. California Department of Food and Agriculture.

Chan, M. T., Selvam, A., and Wong, J. W. (2016). Reducing nitrogen loss and salinity during 'struvite' food waste composting by zeolite amendment. Bioresour. Technol. 200, 838-844. doi: 10.1016/j.biortech.2015.10.093

Chen, H., Awasthi, M. K., Liu, T., Zhao, J., Ren, X., Wang, M., et al. (2018). Influence of clay as additive on greenhouse gases emission and maturity evaluation during chicken manure composting. Bioresour. Technol. 266, 82-88. doi: 10.1016/j.biortech.2018.06.073

Chen, W., Liao, X., Wu, Y., Liang, J. B., Mi, J., Huang, J., et al. (2017). Effects of different types of biochar on methane and ammonia mitigation during layer manure composting. Waste Manage. 61, 506-515. doi: 10.1016/j.wasman.2017.01.014

Davis, C. G., and Hahn, W. (2016). Assessing the Status of the Global Dairy Trade. New York, NY: The International Food and Agribusiness Management Review.

de la Fuente, G., Yañez-Ruiz, D. R., Seradj, A. R., Balcells, J., and Belanche, A. (2019). Methanogenesis in animals with foregut and hindgut fermentation: a review. Animal Produc. Sci. 59, 2109-2122. doi: 10.1071/AN17701

de Vries, M., and de Boer, I. J. (2010). Comparing environmental impacts for livestock products: a review of life cycle assessments. Livest. Sci. 128, 1-11. doi: 10.1016/j.livsci.2009.11.007

Dijkstra, J., Bannink, A., Bosma, P. M., Lantinga, E. A., and Reijs, J. W. (2018a). Modeling the effect of nutritional strategies for dairy cows on the composition of excreta nitrogen. Front. Sustain. Food Syst. 2:63. doi: 10.3389/fsufs.2018.00063

Dijkstra, J., Bannink, A., France, J., E., Kebreab, S., and van Gastelen. (2018b). Antimethanogenic effects of 3-nitrooxypropanol depend on supplementation dose, dietary fiber content, cattle type. J. Dairy Sci. 101, 9041-9047. doi: 10.3168/jds.2018-14456

Dijkstra, J., Oenema, O., Van Groenigen, J., Spek, J., Van Vuuren, A., and Bannink, A. (2013). Diet effects on urine composition of cattle and $\mathrm{N} 2 \mathrm{O}$ emissions. Animal 7(Suppl 2):292-302. doi: 10.1017/S1751731113000578

Doreau, M., Rochette, Y., and Martin, C. (2012). Effect of type of forage (maize silage vs grass silage) and protein source (soybean meal vs dehydrated lucerne) in dairy cow diet on methane emission and on nitrogen losses. In: Proc. International Symposium on Emission of Gas and Dust From Livestock. SaintMalo.

Duan, Y., Awasthi, S. K., Liu, T., Verma, S., Wang, Q., Chen, H., et al. (2019). Positive impact of biochar alone and combined with bacterial consortium amendment on improvement of bacterial community during cow manure composting. Bioresour. Technol. 280, 79-87. doi: 10.1016/j.biortech.2019.02.026

Duin, E. C., Wagner, T., Shima, S., Prakash, D., Cronin, B., Yáñez-Ruiz, D. R., et al. (2016). Mode of action uncovered for the specific reduction of methane emissions from ruminants by the small molecule 3-nitrooxypropanol. Proc. Nat. Acad. Sci. U.S.A. 113, 6172-6177. doi: 10.1073/pnas.1600298113

Dustan, A. (2002). Review of Methane and Nitrous Oxide Emission Factors for Manure Management in Cold Climates. JTI-rapport 299. Uppsala: Instituet for jordbruks - och miljoeteknik, JTI.

Edouard, N., Charpiot, A., Robin, P., Lorinquer, E., Dollé J. B., and Faverdin, P. (2019). Influence of diet and manure management on ammonia and greenhouse gas emissions from dairy barns. Animal 13, 2903-2912. doi: $10.1017 /$ S1751731119001368

Elcoso, G., Zweifel, B., and Bach, A. (2019). Effects of a blend of essential oils on milk yield and feed efficiency of lactating dairy cows. Appl. Animal Sci. 35, 304-311. doi: 10.15232/aas.2018-01825 
Ellis, J. L., Dijkstra, J., Kebreab, E., Bannink, A., Odongo, N. E., McBride, B. W., et al. (2008). Aspects of rumen microbiology central to mechanistic modelling of methane production in cattle. J. Agric. Sci. 146, 213-233. doi: $10.1017 /$ S0021859608007752

Fang, M., Wong, J., Ma, K., and Wong, M. H. (1999). Co-composting of sewage sludge and coal fly ash: nutrient transformations. Bioresour. Technol. 67, 19-24. doi: 10.1016/S0960-8524(99)00095-4

FAO (2009). "Milk/dairy products," in Agribusiness Handbook. Rome: Food and Agriculture Organization of the United Nations.

FAO, F. et al. (1997). FAOSTAT Statistical Database. FAO: Rome.

Febrisiantosa, A., Ravindran, B., and Choi, H. (2018). The effect of co-additives (Biochar and FGD Gypsum) on ammonia volatilization during the composting of livestock waste. Sustainability 10:795. doi: 10.3390/su10030795

Filipy, J., Rumburg, B., Mount, G., Westberg, H., and Lamb, B. (2006). Identification and quantification of volatile organic compounds from a dairy. Atmos. Environ. 40, 1480-1494. doi: 10.1016/j.atmosenv.2005.10.048

Gerber, P. J., Henderson, B., and Makkar, H. P. (2013). Mitigation of greenhouse gas emissions in livestock production: a review of technical options for non$\mathrm{CO}_{2}$ emissions. No. 177. Food and Agriculture Organization of the United Nations (FAO).

Gil, Á., and Ortega, R. M. (2019). Introduction and executive summary of the supplement, role of milk and dairy products in health and prevention of noncommunicable chronic diseases: a series of systematic reviews. $A d v$. Nutrition 10, S67-S73. doi: 10.1093/advances/nmz020

Godlewska, P., Schmidt, H. P., Ok, Y. S., and Oleszczuk, P. (2017). Biochar for composting improvement and contaminants reduction. A review. Bioresource Tech. 246, 193-202. doi: 10.1016/j.biortech.2017.07.095

Guo, X., Huang, J., Lu, Y., Shan, G., and Li, Q. (2016). The influence of flue gas desulphurization gypsum additive on characteristics and evolution of humic substance during co-composting of dairy manure and sugarcane pressmud. Bioresour. Technol. 219, 169-174. doi: 10.1016/j.biortech.2016.07.125

Guyader, J., Eugène, M., Doreau, M., Morgavi, D., Gérard, C., Loncke, C., et al. (2015). Nitrate but not tea saponin feed additives decreased enteric methane emissions in nonlactating cows. J. Anim. Sci. 93, 5367-5377. doi: $10.2527 /$ jas.2015-9367

Haisan, J., Sun, Y., Guan, L., Beauchemin, K. A., Iwaasa, A., Duval, S., et al. (2017). The effects of feeding 3-nitrooxypropanol at two doses on milk production, rumen fermentation, plasma metabolites, nutrient digestibility, and methane emissions in lactating Holstein cows. Animal Produc. Sci. 57, 282-289. doi: 10.1071/AN15219

Hao, X., Larney, F. J., Chang, C., Travis, G. R., Nichol, C. K., and Bremer, E. (2005). The effect of phosphogypsum on greenhouse gas emissions during cattle manure composting. J. Environ. Qual. 34, 774-781. doi: 10.2134/jeq2004.0388

Hart, K. J., Jones, H. G., Waddams, K. E., Worgan, H. J., Zweifel, B., and Newbold, C. J. (2019). An essential oil blend decreases methane emissions and increases milk yield in dairy cows. Open J. Animal Sci. 9:259. doi: 10.4236/ojas.2019.93022

He, S., Fan, X., Katukuri, N. R., Yuan, X., F., Wang, and, R.-B., et al. (2016). Enhanced methane production from microalgal biomass by anaerobic bio-pretreatment. Bioresour. Technol. 204, 145-151. doi: 10.1016/j.biortech.2015.12.073

He, X., Yin, H., Han, L., Cui, R., Fang, C., and Huang, G. (2019). Effects of biochar size and type on gaseous emissions during pig manure/wheat straw aerobic composting: Insights into multivariate-microscale characterization and microbial mechanism. Bioresour. Technol. 271, 375-382. doi: 10.1016/j.biortech.2018.09.104

Herrero, M., Grace, D., Njuki, J., Johnson, N., Enahoro, D., Silvestri, S., et al. (2013). The roles of livestock in developing countries. Animal 7:3. doi: $10.1017 /$ S1751731112001954

Hindrichsen, I., Wettstein, H.-R., Machmüller, A., and Kreuzer, M. (2006). Methane emission, nutrient degradation and nitrogen turnover in dairy cows and their slurry at different milk production scenarios with and without concentrate supplementation. Agric. Ecosyst. Environ. 113, 150-161. doi: 10.1016/j.agee.2005.09.004

Hirahatake, K. M., Slavin, J. L., Maki, K. C., and Adams, S. H. (2014). Associations between dairy foods, diabetes, and metabolic health: potential mechanisms and future directions. Metab. Clin. Exp. 63, 618-627. doi: 10.1016/j.metabol.2014.02.009
Holland, E. (2017). Investigation of Ammonia and Nitrate Removal from Municipal Wastewater Using BiOWiSH.

Hristov, A. N., Bannink, A., Crompton, L. A., Huhtanen, P., Kreuzer, M., McGee, M., et al. (2019). Invited review: nitrogen in ruminant nutrition: a review of measurement techniques. J. Dairy Sci. 102, 5811-5852. doi: 10.3168/jds.2018-15829

Hristov, A. N., Hanigan, M., Cole, A., Todd, R., McAllister, T. A., Ndegwa, P. M., et al. (2011). Ammonia emissions from dairy farms and beef feedlots. Can. J. Anim. Sci. 91, 1-35. doi: 10.4141/CJAS10034

Hristov, A. N., Lee, C., Cassidy, T., Heyler, K., Tekippe, J., Varga, G., et al. (2013a). Effect of Origanum vulgare L. leaves on rumen fermentation, production, and milk fatty acid composition in lactating dairy cows. J. Dairy Sci. 96, 1189-1202. doi: $10.3168 /$ jds.2012-5975

Hristov, A. N., Oh, J., Firkins, J., Dijkstra, J., Kebreab, E., Waghorn, G., et al. (2013b). Special topics-Mitigation of methane and nitrous oxide emissions from animal operations: I. A review of enteric methane mitigation options. J. Animal Sci. 91, 5045-5069. doi: 10.2527/jas.2013-6583

Hristov, A. N., Oh, J., Giallongo, F., Frederick, T. W., Harper, M. T., Weeks, H. L., et al. (2015). An inhibitor persistently decreased enteric methane emission from dairy cows with no negative effect on milk production. Proc. Nat. Acad. Sci. U.S.A. 112, 10663-10668. doi: 10.1073/pnas.1504124112

Hungate, R. E. (2013). The Rumen and Its Microbes. New York: Elsevier.

Immig, I. (1996). The rumen and hindgut as source of ruminant methanogenesis. Environ. Monit. Assess. 42, 57-72. doi: 10.1007/BF00394042

IPCC (2014). Climate Change 2014: Synthesis Report. Contribution of Working Groups I, II and III to the Fifth Assessment Report of the Intergovernmental Panel on Climate Change. IPCC, Geneva, Switzerland.

Ivan, M., Mir, P., Mir, Z., Entz, T., He, M., and McAllister, T. (2004). Effects of dietary sunflower seeds on rumen protozoa and growth of lambs. Br. J. Nutrition 92, 303-310. doi: 10.1079/BJN20041178

Janssen, P. H., and Kirs, M. (2008). Structure of the archaeal community of the rumen. Appl. Environ. Microbiol. 74, 3619-3625. doi: 10.1128/AEM.02812-07

Jayanegara, A., Leiber, F., and Kreuzer, M. (2012). Meta-analysis of the relationship between dietary tannin level and methane formation in ruminants from in vivo and in vitro experiments. J. Anim. Physiol. Anim. Nutr. 96, 365-375. doi: 10.1111/j.1439-0396.2011.01172.x

Jindo, K., Sánchez-Monedero, M. A., Hernández, T., García, C., Furukawa, T., Matsumoto, K., et al. (2012). Biochar influences the microbial community structure during manure composting with agricultural wastes. Sci. Total Environ. 416, 476-481. doi: 10.1016/j.scitotenv.2011.12.009

Johnson, D., Phetteplace, H., and Seidl, A. (2002). Methane, Nitrous Oxide and Carbon Dioxide Emissions From Ruminant Livestock Production Systems. Elsevier; Amsterdam: The Netherlands 77-85.

Johnson, K. A., and Johnson D. E. (1995). Methane emissions from cattle. J. Anim. Sci. 73:2483-2492. doi: 10.2527/1995.7382483x

Juodeikiene, G., Cizeikiene, D., Glasner, C., Bartkiene, E., Dikiy, A., Shumilina, E., et al. (2017). Evaluation of the potential of utilizing lactic acid bacteria and dairy wastewaters for methane production. Energy Explor. Exploitation 35, 388-402. doi: $10.1177 / 0144598717698081$

Kaspar, H., and Tiedje, J. (1981). Dissimilatory reduction of nitrate and nitrite in the bovine rumen: nitrous oxide production and effect of acetylene. Appl. Environ. Microbiol. 41, 705-709. doi: 10.1128/aem.41.3.705-709.1981

Klop, G., Dijkstra, J., Dieho, K., Hendriks, W., and Bannink, A. (2017a). Enteric methane production in lactating dairy cows with continuous feeding of essential oils or rotational feeding of essential oils and lauric acid. J. Dairy Sci. 100, 3563-3575. doi: 10.3168/jds.2016-12033

Klop, G., Hatew, B., Bannink, A., and Dijkstra, J. (2016). Feeding nitrate and docosahexaenoic acid affects enteric methane production and milk fatty acid composition in lactating dairy cows. J. Dairy Sci. 99, 1161-1172. doi: $10.3168 /$ jds.2015-10214

Klop, G., Van Laar-van Schuppen, S., Pellikaan W., Hendriks, W., Bannink, A., and Dijkstra, J. (2017b). Changes in in vitro gas and methane production from rumen fluid from dairy cows during adaptation to feed additives in vivo. Animal 11, 591-599. doi: 10.1017/S1751731116002019

Knapp, J. R., Laur, G., Vadas, P. A., Weiss, W. P., and Tricarico, J. M. (2014). Invited review: enteric methane in dairy cattle production: quantifying the opportunities and impact of reducing emissions. J. Dairy Sci. 97, 3231-3261. doi: $10.3168 /$ jds.2013-7234 
Knips, V. (2005). Developing Countries and the Global Dairy Sector Part I global Overview.

Knowlton, K., and Cobb T. D. (2006). ADSA Foundation Scholar Award: implementing waste solutions for dairy and livestock farms. J. Dairy Sci. 89, 1372-1383. doi: 10.3168/jds.S0022-0302(06)72205-6

Kreuzer, M., and Hindrichsen, I. (2006). "Methane mitigation in ruminants by dietary means: the role of their methane emission from manure," in Proc. International Congress Series. Zurich: Elsevier 199-208. doi: 10.1016/j.ics.2006.01.015

Külling, D., Menzi, H., Sutter, F., Lischer, P., and Kreuzer, M. (2003). Ammonia, nitrous oxide and methane emissions from differently stored dairy manure derived from grass-and hay-based rations. Nutrient Cycling Agroecosyst. 65, 13-22. doi: 10.1023/A:1021857122265

Lee, C., and Beauchemin, K. A. (2014). A review of feeding supplementary nitrate to ruminant animals: nitrate toxicity, methane emissions, production performance. Can. J. Anim. Sci. 94, 557-570. doi: 10.4141/cjas-2014-069

Lee, C., Hristov, A. N., Dell, C. J., Feyereisen, G., Kaye, J., and Beegle, D. (2012). Effect of dietary protein concentration on ammonia and greenhouse gas emitting potential of dairy manure. J. Dairy Sci. 95, 1930-1941. doi: $10.3168 /$ jds.2010-4141

Lee, E. (2012). Investigation of a commercial product (BiOWiSH TM) for nitrogen management (Masters thesis). California Polytechnic State University San Luis Obispo; CalPoly Digital Commons.

Leng, R., and Preston, T. (2010). Further considerations of the potential of nitrate as a high affinity electron acceptor to lower enteric methane production in ruminants. Livestock Res. Rural Dev. 22:221.

Li, R., Wang, Q., Zhang, Z., Zhang, G., Li, Z., Wang, L., et al. (2015). Nutrient transformation during aerobic composting of pig manure with biochar prepared at different temperatures. Environ. Technol. 36, 815-826. doi: 10.1080/09593330.2014.963692

Li, Y., Luo, W., Li, G., Wang, K., and Gong, X. (2018). Performance of phosphogypsum and calcium magnesium phosphate fertilizer for nitrogen conservation in pig manure composting. Bioresour. Technol. 250, 53-59. doi: 10.1016/j.biortech.2017.07.172

Lopes, J., de Matos, L., Harper, M., Giallongo, F., Oh, J., Gruen, D., et al. (2016). Effect of 3-nitrooxypropanol on methane and hydrogen emissions, methane isotopic signature, and ruminal fermentation in dairy cows. J. Dairy Sci. 99, 5335-5344. doi: 10.3168/jds.2015-10832

Lovett, D., Shalloo, L., Dillon, P., and O'Mara, F. (2006). A systems approach to quantify greenhouse gas fluxes from pastoral dairy production as affected by management regime. Agric. Syst. 88, 156-179. doi: 10.1016/j.agsy.2005.03.006

Lund, P., Dahl, R., Yang, H., Hellwing, A. L. F., Cao, B., and Weisbjerg, M. R. (2014). The acute effect of addition of nitrate on in vitro and in vivo methane emission in dairy cows. Animal Produc. Sci. 54, 1432-1435. doi: 10.1071/AN14339

Madureira, A., Tavares, T., Gomes, A. M., Pintado, M., and Malcata, F. X. (2010). Invited review: physiological properties of bioactive peptides obtained from whey proteins. J. Dairy Sci. 93, 437-455. doi: 10.3168/jds.2009-2566

Mao, H., Lv, Z., Sun, H., Li, R., Zhai, B., Wang, Z., et al. (2018). Improvement of biochar and bacterial powder addition on gaseous emission and bacterial community in pig manure compost. Bioresour. Technol. 258, 195-202. doi: 10.1016/j.biortech.2018.02.082

Mao, H., Zhang, T., Li, R., Zhai, B., Wang, Z., Wang, Q., et al. (2017). Apple pomace improves the quality of pig manure aerobic compost by reducing emissions of NH 3 and N 2 O. Sci. Rep. 7:13537. doi: 10.1038/s41598-017-00987-y

Martínez-Fernández, G., Abecia, L., Arco, A., Cantalapiedra-Hijar, G., MartínGarcía, A., Molina-Alcaide, E., et al. (2014). Effects of ethyl-3-nitrooxy propionate and 3-nitrooxypropanol on ruminal fermentation, microbial abundance, and methane emissions in sheep. J. Dairy Sci. 97, 3790-3799. doi: $10.3168 /$ jds.2013-7398

McCaughey, W., Wittenberg, K., and Corrigan, D. (1999). Impact of pasture type on methane production by lactating beef cows. Can. J. Anim. Sci. 79, 221-226. doi: 10.4141/A98-107

Meller, R., Wenner, B., Ashworth, J., Gehman, A., Lakritz, J., and Firkins, J. (2019). Potential roles of nitrate and live yeast culture in suppressing methane emission and influencing ruminal fermentation, digestibility, and milk production in lactating Jersey cows. J. Dairy Sci. 102, 6144-6156. doi: 10.3168/jds.2018-16008
Milani, F., Nutter, D., and Thoma, G. (2011). Invited review: environmental impacts of dairy processing and products: a review. J. Dairy Sci. 94, 4243-4254. doi: 10.3168/jds.2010-3955

Miller, L., Moorby, J. M., Davies, D. R., Humphreys, M. O., Scollan, N. D., MacRae, J. C., et al. (2001). Increased concentration of watersoluble carbohydrate in perennial ryegrass (Lolium perenne L.): milk production from late-lactation dairy cows. Grass Forage Sci. 56, 383-394. doi: 10.1046/j.1365-2494.2001.00288.x

Mills, J., Crompton, L., and Reynolds, C. (2008). Ruminant Nutrition Regimes to Reduce Methane and Nitrogen Emissions-a Meta-Analysis of Current Databases. Final Project Report 1600:04.

Moe, P., and Tyrrell, H. (1979). Methane production in dairy cows. J. Dairy Sci. 62, 1583-1586. doi: 10.3168/jds.S0022-0302(79)83465-7

Muck, R. E. (1982). Urease activity in bovine feces. J. Dairy Sci. 65, 2157-2163. doi: $10.3168 /$ jds.S0022-0302(82)82475-2

Murray, R., Bryant, A., and Leng, R. (1976). Rates of production of methane in the rumen and large intestine of sheep. Br. J. Nutrition 36, 1-14. doi: 10.1079/BJN19760053

Naranjo, A., Johnson, A., Rossow, H., and Kebreab, E. (2020). Greenhouse gas, water, and land footprint per unit of production of the California dairy industry over 50 years. J. Dairy Sci. doi: 10.3168/jds.2019-16576

National Research Council, N. (2001). Nutrient Requirements of Dairy Cattle, 7th $E d n$. Washington, DC: The National Academies Press.

O’Keefe, M. (2018). Data: Dairy's Positive Impact on U.S. Economy. Vol. 2020. U.S. Dairy Export Council.

Outlook, F. (2020). Biannual Report on Global Food Markets [Electronic Resource]. Food and Agriculture Organization of the United Nations.

Pal, N. (2012). A white paper on Effect and Efficacy of BiOWiSHTM for Reducing Solids in Dairy Wastewater. [Electronic Resource]. Available online at: https:// cead874f5bbdd4b43a5cfad5b9385501cb7f7cac4f09f1c56222.ssl.cf5.rackcdn. com/White\%20Papers/cal-poly-wwt-white-paper-dairy-manure.pdf

Parsons, A., Rowarth, J., and Rasmussen, S. (2012). High-sugar grasses. Plant Sci. Rev. 2011:187. doi: 10.1079/PAVSNNR20116046

Peterson, C. B., El Mashad, H. M., Zhao, Y., Pan, Y., and Mitloehner, F. M. (2020). Effects of SOP lagoon additive on gaseous emissions from stored liquid dairy manure. Sustainability 12:1393. doi: 10.3390/su12041393

Pinares-Patiño, C., Baumont, R., and Martin, C. (2003). Methane emissions by Charolais cows grazing a monospecific pasture of timothy at four stages of maturity. Can. J. Anim. Sci. 83, 769-777. doi: 10.4141/A03-034

Place, S. E., and Mitloehner, F. (2010). Invited review: contemporary environmental issues: a review of the dairy industry's role in climate change and air quality and the potential of mitigation through improved production efficiency. J. Dairy Sci. 93, 3407-3416. doi: 10.3168/jds.2009-2719

Pryce, J. E., and Haile-Mariam M. (2020). Symposium review: genomic selection for reducing environmental impact and adapting to climate change. J. Dairy Sci. doi: $10.3168 /$ jds.2019-17732

Reynolds, C. K., Humphries, D. J., Kirton, P., Kindermann, M., Duval, S., and Steinberg, W. (2014). Effects of 3-nitrooxypropanol on methane emission, digestion, and energy and nitrogen balance of lactating dairy cows. J. Dairy Sci. 97, 3777-3789. doi: 10.3168/jds.2013-7397

Rodriguez Chiang, L. M. (2011). Methane Potential of Sewage Sludge to Increase Biogas Production.

Romero-Perez, A., Okine, E., McGinn, S., Guan, L., Oba, M., Duval, S., et al. (2015). Sustained reduction in methane production from long-term addition of 3-nitrooxypropanol to a beef cattle diet. J. Anim. Sci. 93, 1780-1791. doi: $10.2527 /$ jas.2014-8726

Santos, M., Robinson, P., Williams, P., and Losa, R. (2010). Effects of addition of an essential oil complex to the diet of lactating dairy cows on whole tract digestion of nutrients and productive performance. Anim. Feed Sci. Technol. 157, 64-71. doi: 10.1016/j.anifeedsci.2010.02.001

Shaw, S. L., Mitloehner, F. M., Jackson, W., DePeters, E. J., Fadel, J. G., Robinson, P. H., et al. (2007). Volatile organic compound emissions from dairy cows and their waste as measured by proton-transfer-reaction mass spectrometry. Environ. Sci. Tech. 41, 1310-1316. doi: 10.1021/es061475e

Siekmann, J. H., Allen, L. H., Bwibo, N. O., Demment, M. W., Murphy, S. P., and Neumann, C. G. (2003). Kenyan school children have multiple micronutrient deficiencies, but increased plasma vitamin B-12 is the only detectable 
micronutrient response to meat or milk supplementation. J. Nutrition 133, 3972S-3980S. doi: 10.1093/jn/133.11.3972S

Steinfeld, H., Gerber, P., Wassenaar, T., Castel, V., Rosales, M., M., de Haan, C., et al. (2006). Livestock's Long Shadow: Environmental Issues and Options. Food and Agriculture Org.

Sumner, D. A., and Matthews, W. A. (2019). Contributions of the California Dairy Industry to the California Economy in 2018. University of California, Agricultural Issues Center.

Sun, H., Pan, Y., Zhao, Y., Jackson, W. A., Nuckles, L. M., Malkina, I. L., et al. (2008). Effects of sodium bisulfate on alcohol, amine, and ammonia emissions from dairy slurry. J. Environ. Qual. 37, 608-614. doi: 10.2134/jeq2006.0446

Tavendale, M. H., Meagher, L. P., Pacheco, D., Walker, N., Attwood, G. T., and Sivakumaran, S. (2005). Methane production from in vitro rumen incubations with Lotus pedunculatus and Medicago sativa, and effects of extractable condensed tannin fractions on methanogenesis. Anim. Feed Sci. Technol. 123, 403-419. doi: 10.1016/j.anifeedsci.2005.04.037

Tekippe, J., Hristov, A. N., Heyler, K., Cassidy, T., Zheljazkov, V., Ferreira, J., et al. (2011). Rumen fermentation and production effects of Origanum vulgare L. leaves in lactating dairy cows. J. Dairy Sci. 94, 5065-5079. doi: $10.3168 /$ jds.2010-4095

Thorning, T. K., Raben, A., Tholstrup, T., Soedamah-Muthu, S. S., Givens, I., and Astrup, A. (2016). Milk and dairy products: good or bad for human health? An assessment of the totality of scientific evidence. Food Nutrition Res. 60:32527. doi: $10.3402 /$ fnr.v60.32527

Tubail, K., Chen, L., Michel Jr, F. C., Keener, H. M., Rigot, J. F., Klingman, M., et al. (2008). Gypsum additions reduce ammonia nitrogen losses during composting of dairy manure and biosolids. Compost Sci. Utilization 16, 285-293. doi: 10.1080/1065657X.2008.10702390

USDA (2020). Milk Production. National Agricultural Statistics Service, United States Department of Agriculture (2020).

Van Zijderveld, S., Gerrits, W., Dijkstra, J., Newbold, J., Hulshof, R., and Perdok, H. (2011). Persistency of methane mitigation by dietary nitrate supplementation in dairy cows. J. Dairy Sci. 94, 4028-4038. doi: 10.3168/jds.2011-4 236

Vandecasteele, B., Sinicco, T., D’Hose, T., Nest, T. V., and Mondini, C. (2016). Biochar amendment before or after composting affects compost quality and $\mathrm{N}$ losses, but not P plant uptake. J. Environ. Manage. 168, 200-209. doi: 10.1016/j.jenvman.2015.11.045

Velthof, G., Van Beusichem, M., and Oenema, O. (1998). "Mitigation of nitrous oxide emission from dairy farming systems," in Nitrogen, the Confer-Ns (Noordwijkerhout: Elsevier), 173-178. doi: 10.1016/B978-0-08-043201-4.50028-9

Visioli, F., and Strata A. (2014). Milk, dairy products, and their functional effects in humans: a narrative review of recent evidence. Adv. Nutr. 5, 131-143. doi: 10.3945/an.113.005025

Von Keyserlingk, M., Martin, N., Kebreab, E., Knowlton, K., Grant, R., Stephenson, M., et al. (2013). Invited review: sustainability of the US dairy industry. J. Dairy Sci. 96, 5405-5425. doi: 10.3168/jds.2012-6354

Vyas, D., McGinn, S., Duval, S., Kindermann, M., and Beauchemin, K. (2016). Effects of sustained reduction of enteric methane emissions with dietary supplementation of 3-nitrooxypropanol on growth performance of growing and finishing beef cattle. J. Anim. Sci. 94, 2024-2034. doi: 10.2527/jas.2015-0268
Waghorn, G. (2008). Beneficial and detrimental effects of dietary condensed tannins for sustainable sheep and goat production-Progress and challenges. Anim. Feed Sci. Technol. 147, 116-139. doi: 10.1016/j.anifeedsci.2007.09.013

Wang, M., Awasthi, M. K., Wang, Q., Chen, H., Ren, X., Zhao, J., et al. (2017). Comparison of additives amendment for mitigation of greenhouse gases and ammonia emission during sewage sludge co-composting based on correlation analysis. Bioresour. Technol. 243, 520-527. doi: 10.1016/j.biortech.2017.06.158

Wang, Q., Wang, Z., Awasthi, M. K., Jiang, Y., Li, R., Ren, X., et al. (2016). Evaluation of medical stone amendment for the reduction of nitrogen loss and bioavailability of heavy metals during pig manure composting. Bioresour. Technol. 220, 297-304. doi: 10.1016/j.biortech.2016. 08.081

Wolf, C. A. (2003). The economics of dairy production. Vet. Clinics 19, 271-293. doi: $10.1016 / 50749-0720(03) 00028-8$

Wong, J. W.-C., Fung, S. O., and Selvam, A. (2009). Coal fly ash and lime addition enhances the rate and efficiency of decomposition of food waste during composting. Bioresour. Technol. 100, 3324-3331. doi: 10.1016/j.biortech.2009.01.063

Woodward, S., Waghorn, G., Lassey, K., and Laboyrie, P. (2002). "Does feeding sulla (Hedysarum coronarium) reduce methane emissions from dairy cows?," in Proc. Proceedings-New Zealand Society of Animal Production. New Zealand Society of Animal Production (1999). p. 227-230.

Wu, H., Lai, C., Zeng, G., Liang, J., Chen, J., Xu, J., et al. (2017). The interactions of composting and biochar and their implications for soil amendment and pollution remediation: a review. Crit. Rev. Biotechnol. 37, 754-764. doi: 10.1080/07388551.2016.1232696

Xu, W., Fu, S., Yang, Z., Lu, J., and Guo, R. (2018). Improved methane production from corn straw by microaerobic pretreatment with a pure bacteria system. Bioresour. Technol. 259, 18-23. doi: 10.1016/j.biortech.2018.02.046

Yang, F., Li, G., Shi, H., and Wang, Y. (2015). Effects of phosphogypsum and superphosphate on compost maturity and gaseous emissions during kitchen waste composting. Waste Manage 36, 70-76. doi: 10.1016/j.wasman.2014.11.012

Conflict of Interest: The authors declare that the research was conducted in the absence of any commercial or financial relationships that could be construed as a potential conflict of interest.

Publisher's Note: All claims expressed in this article are solely those of the authors and do not necessarily represent those of their affiliated organizations, or those of the publisher, the editors and the reviewers. Any product that may be evaluated in this article, or claim that may be made by its manufacturer, is not guaranteed or endorsed by the publisher.

Copyright $\odot 2021$ Peterson and Mitloehner. This is an open-access article distributed under the terms of the Creative Commons Attribution License (CC BY). The use, distribution or reproduction in other forums is permitted, provided the original author(s) and the copyright owner(s) are credited and that the original publication in this journal is cited, in accordance with accepted academic practice. No use, distribution or reproduction is permitted which does not comply with these terms. 